\title{
Molecular detection of Hematodinium spp. in Norway lobster Nephrops norvegicus and other crustaceans
}

\author{
H. J. Small ${ }^{1,4, *}$, D. M. Neil ${ }^{1}$, A. C. Taylor ${ }^{1}$, R. J. A. Atkinson ${ }^{2}$, G. H. Coombs ${ }^{3}$ \\ ${ }^{1}$ Division of Environmental and Evolutionary Biology, and ${ }^{3}$ Division of Infection \& Immunity, Institute of Biomedical \\ and Life Sciences, University of Glasgow, Glasgow G12 8QQ, UK \\ ${ }^{2}$ University Marine Biological Association, Millport, Isle of Cumbrae KA28 0EG, UK \\ ${ }^{4}$ Present address: Virginia Institute of Marine Science, College of William and Mary, Gloucester Point, Virginia 23062, USA
}

\begin{abstract}
The Norway lobster Nephrops norvegicus (L.) from the coastal waters of Scotland is seasonally infected by a parasitic dinoflagellate of the genus Hematodinium. Methods used to detect infection include a morphological index (pleopod diagnosis) and several immunoassays. The present study describes the development and application of a set of Hematodinium-specific polymerase chain reaction (PCR) primers and DNA probes based on Hematodinium ribosomal DNA (rDNA). In the PCR assay, a diagnostic band of $380 \mathrm{bp}$ was consistently amplified from total genomic DNA isolated from Hematodinium-infected $N$. norvegicus. The sensitivity of the assay was 1 ng DNA, which is equivalent to 0.6 parasites. The primer pair also detected Hematodinium DNA in preparations of the amphipod Orchomene nanus, indicating that the amphipod may be infected with the same Hematodinium sp. infecting $N$. norvegicus. DNA probes detected Hematodinium parasites in heart, hepatopancreas and gill tissues from $N$. norvegicus, and hepatopancreas and gill tissues from Carcinus maenas, confirming Hematodinium infection in the latter.
\end{abstract}

KEY WORDS: Hematodinium · Parasite $\cdot$ Norway lobster $\cdot$ Molecular detection Resale or republication not permitted without written consent of the publisher

\section{INTRODUCTION}

Infection of the Norway lobster Nephrops norvegicus by a parasitic dinoflagellate of the genus Hematodinium has been described from a number of locations around the West Coast of Scotland and the Irish Sea (Field et al. 1992, 1998, Briggs \& McAliskey 1996, 2002, Appleton et al. 1997). In UK waters, the edible crab Cancer pagurus has also recently been found to harbour Hematodinium spp. (Stentiford et al. 2002). Parasitic Hematodinium species have previously been reported infecting several decapod crustaceans including Callinectes sapidus (Newman \& Johnson 1975, Messick 1994, Messick \& Shields 2000), Cancer pagurus (Latrouite et al. 1988), Chionoecetes bairdi (Meyers et al. 1987, Love et al. 1993), Chionoecetes opilio (Taylor \& Khan 1995), Necora puber (Wilhelm \& Mialhe
1996), Ovalipes ocellatus (MacLean \& Ruddell 1978) and Portunus pelagicus (Hudson \& Shields 1994). In each of the above examples, infection by Hematodinium species caused serious mortalities in the host decapod population.

Previous methods to diagnose infection of Nephrops norvegicus by Hematodinium species include an assessment of the external colouration of the carapace and appendages of infected lobsters. However this diagnostic method lacks sensitivity and only advanced infections can be reliably identified (Stentiford et al. 2001a). The pleopods of infected lobsters can be examined under low power light microscopy for the aggregation of parasites in the vasculature (Field \& Appleton 1995). The severity of infection was classified on a 5-point scale, from apparently uninfected to an advanced infection. The pleopod method is reliable as a 
field method for identifying advanced infections, but cannot detect tissue-based and low-level haemolymph infection. Immunological methods including an indirect fluorescent antibody technique (IFAT), Western blot and enzyme linked immunosorbent assay (ELISA) have all been developed using a polyclonal rabbit antiserum raised against a mixed in vitro culture of vegetative forms of Hematodinium from N. norvegicus (Field \& Appleton 1996, Stentiford et al. 2001b, Small et al. 2002). However, the polyclonal antibody cross-reacts with epitopes found on other protozoan parasites (Bushek et al. 2002) and may not recognise in vivo life cycle stages of Hematodinium species that were absent from the original innoculum or present only in other hosts. Because of the above concerns and the need for more sensitive and specific diagnostic methods, a molecular approach to parasite detection was undertaken.

DNA-based diagnostic methods utilising the polymerase chain reaction (PCR) and in situ hybridisation (ISH) assays have facilitated diagnosis of many marine pathogens of shellfish (for review see Cunningham 2002). Nuclear ribosomal DNA (rDNA) is widely acknowledged as a useful target for the definition of genetic markers informative at several levels (Gasser \& Zhu 1999). The rate of evolution varies between different regions of rDNA, resulting in target sequences ranging from highly conserved to highly variable (Hillis \& Dixon 1991). PCR primers used to diagnose Hematodinium infection in crustacean hosts have previously been reported (Hudson \& Adlard 1994, Gruebl et al. 2002). However, both primer sets used in those studies were located in the conserved $18 \mathrm{~S}$ and $5.8 \mathrm{~S}$ regions of the rDNA complex and are not specific for individual Hematodinium species. Variable regions of rDNA from other dinoflagellates have been identified allowing species-specific PCR assays to be developed (Litaker et al. 2003). We describe herein the development and application of PCR and ISH assays for detection of Hematodinium species infection in Nephrops norvegicus and other crustaceans.

\section{MATERIALS AND METHODS}

Sample collection and preparation. Norway lobsters Nephrops norvegicus and other crustaceans used in this study (unless indicated otherwise) were caught by otter bottom-trawl (70 mm mesh size) south of Little Cumbrae in the Clyde Sea Area, Scotland, UK. Haemolymph samples were taken from the base of the fifth pereiopod, using a sterile $1 \mathrm{ml}$ disposable syringe and 25-gauge needle, and were frozen at $-20^{\circ} \mathrm{C}$. Samples were assayed for the presence of Hematodinium by the ELISA method of Small et al. (2002). Infected and uninfected haemolymph samples were retained for DNA isolation. For lobsters having a low-level infection (as indicated by ELISA), a subsample of the same haemolymph was used to estimate parasite cell numbers ( $\mathrm{ml}$ haemolymph ${ }^{-1}$ ) using an improved Neubauer counting chamber.

Tissue samples from infected and uninfected lobsters were fixed in Davidson's seawater fixative $(20 \mathrm{ml}$ formalin [40\% v/v], $10 \mathrm{ml}$ glycerol, $10 \mathrm{ml}$ glacial acetic acid, $30 \mathrm{ml} 100 \%$ ethanol, $30 \mathrm{ml}$ seawater) for $24 \mathrm{~h}$, dehydrated in an ethanol series and embedded in paraffin wax. Several other samples of haemolymph and tissue from crustacean and dinoflagellate species commonly found in UK waters were also retained and prepared for DNA extraction (see Table 1). Davidson's fixed-tissue sections from a shore crab (Carcinus maenas) collected from the English Channel with a probable Hematodinium infection were obtained from Dr. G. Stentiford (CEFAS Weymouth Laboratory). H. perezi cells from in vitro culture (Small 2004) were preserved in $100 \%$ ethanol prior to DNA extraction.

To amplify parasite DNA for oligonucleotide primer design, $1 \times 10^{5}$ parasites from an in vitro culture of Hematodinium sp. isolated from the Norway lobster (Appleton \& Vickerman 1998) were collected by centrifugation $\left(1000 \times g\right.$ for $4 \mathrm{~min}$ at $\left.4{ }^{\circ} \mathrm{C}\right)$, the resultant supernatant was removed, and the sedimented cells processed for DNA extraction (see next subsection). The same centrifugation procedure was also carried out for the free-living dinoflagellates Alexandrium tamarense (Culture Collection of Algae and Protozoa, CCAP 1119/5), Gymnodinium catenatum (CCAP 1117/6) (both $1 \times 10^{5}$ cells), $H$. perezi and a Mesanophrys-like parasitic ciliate $\left(5 \times 10^{4}\right.$ cells $)$ prior to DNA extraction.

To examine a possible secondary host for the Hematodinium sp. infecting Nephrops norvegicus, amphipods Orchomene nanus were captured in baited traps from the Hunterston Channel in the Clyde Sea area in August 2001, March 2003 and August 2003, according to the method of Moore \& Wong (1995). Previous studies had indicated that there was a high prevalence of Hematodinium sp. infection of Norway lobsters at this location (J. Atkinson pers. comm.). Individual O. nanus were held for $3 \mathrm{~d}$ in seawater at $12{ }^{\circ} \mathrm{C}$ prior to preservation in $100 \%$ ethanol or Davidson's seawater fixative (only the March 2003 and August 2003 samples). Genomic DNA samples were prepared from each amphipod and assayed by PCR for the presence of Hematodinium spp.

DNA extraction. Genomic DNA was extracted from $100 \mu \mathrm{l}$ haemolymph samples, $100 \mathrm{mg}$ tissue samples, the in vitro Hematodinium sp., ciliate and dinoflagellate pellets, and from individual whole Orchomene nanus according to standard procedures (Sambrook et al. 1989). Briefly, samples were homogenised/ 
resuspended in $250 \mu \mathrm{l}$ extraction buffer $(50 \mathrm{mM}$ Tris, $5 \mathrm{mM}$ EDTA, $100 \mathrm{mM} \mathrm{NaCl}, \mathrm{pH} 8), 100 \mu \mathrm{l}$ of $10 \%$ SDS (w/v) and Proteinase K (0.28 $\left.\mathrm{ng} \mathrm{\mu l}^{-1}\right)$ and incubated at $56^{\circ} \mathrm{C}$ for 18 to $24 \mathrm{~h}$. All DNAs were purified by single-step standard phenol/chloroform (1:1) extraction, precipitated in $550 \mu \mathrm{l} 100 \%$ ethanol using $20 \mu \mathrm{l} 5 \mathrm{M} \mathrm{NaCl}$, and resuspended in $50 \mu \mathrm{l}$ sterile deionised water. DNA concentrations and purity were estimated by measuring the 260/280 optical density ratios using a spectrophotometer (Gene Quant II, Pharmacia Biotech), and adjusted to between 0.1 and $100 \mathrm{ng}$ for experimental use.

Primary amplification, cloning and sequencing. The first internal transcribed spacer (ITS1) and flanking $3^{\prime}$ region of the 18S rDNA complex were amplified independently from 2 Hematodinium genomic DNA templates (in vitro culture and infected haemolymph), using the forward primer 5' GTT CCC CTT GAA CGA GGA ATT C 3' and reverse primer 5' CGC ATT TCG CTG CGT TCT TC 3 '. Primer sequences and amplification conditions were as described by Hudson \& Adlard (1994). Amplification products were run on $1.5 \%(\mathrm{w} / \mathrm{v})$ agarose gels, stained with ethidium bromide, and viewed under UV illumination. Gel images were obtained using a gel documentation system (Appligene). Each amplification product of approximately $680 \mathrm{bp}$ was excised from the agarose gel and purified by the use of a QIA-quick gel-extraction kit (Qiagen). Purified amplification products were ligated into the pGEMT-Easy plasmid vector (Promega) and used to transform Escherichia coli (Strain JM 109) by heat shock according to the manufacturer's instructions. Transformed cells were plated onto LuriaBertani (LB) agar (bacto-agar [1.5\% w/v] in LB medium $\left[\mathrm{NaCl}, 10 \mathrm{~g} \mathrm{l}^{-1}\right.$; bacto-tryptone, $10 \mathrm{~g} \mathrm{l}^{-1}$; yeast extract, $\left.\left.5 \mathrm{~g} \mathrm{l}^{-1}, \mathrm{pH} 7.5\right]\right)$, containing ampicillin $(50 \mu \mathrm{g}$ $\mathrm{ml}^{-1}$ ), isopropyl-beta-D-thiogalactopyranoside (IPTG, $40 \mu \mathrm{g} \mathrm{ml}^{-1}$ ) and 5-bromo-4-chloro-3-indolyl-beta-Dgalactopyranoside (X-gal, $100 \mu \mathrm{g} \mathrm{ml}^{-1}$ ), and grown overnight at $37^{\circ} \mathrm{C}$. Positive transformations were identified by blue/white selection and selected colonies were grown overnight in LB medium containing ampicillin $\left(50 \mu \mathrm{g} \mathrm{ml}^{-1}\right)$. Recombinant plasmids were purified using a miniprep kit (Qiagen) according to the manufacturer's instructions. Plasmid DNA concentrations and purity were estimated by measuring the 260/280 optical density ratios. Ligation of correct products was confirmed by restriction enzyme digestion (ECoRI) and analysis of products on agarose gels. Bi-directional sequencing of 1 clone from a single PCR reaction from each template was performed by MWG-AG Biotech.

Primer and probe design. The nucleotide sequences obtained from initial amplifications were aligned using the software programmes ClustalX 1.81 (Thompson et al. 1994) and BoxShade 3.21 (www.ch.embnet.org/
software/BOX_form.html). Sequences were compared for similarity to those of other dinoflagellates by Basic Local Alignment Tool searches (BLAST; Altschul et al. 1990) in GenBank. Suitable priming regions for PCR exhibiting specificity for the Hematodinium sp. from Nephrops norvegicus were identified from the sequence alignment (see Fig. 1) and by comparison with previously published Hematodinium sp. sequences (Hudson \& Adlard 1996). We designed 4 oligonucleotides, designated 18S F1, 18S F2, 18S R1, and ITS R1 (see Table 2), for PCR and the synthesis of PCRgenerated DNA probes.

PCR assay sensitivity and specificity. The sensitivity of the Hematodinium-specific primers 18S F2 and ITS R1 for use in total genomic DNA sample screening by PCR was assessed by serial dilution of a genomic DNA sample from an infected lobster. The number of Hematodinium sp. cells in the infected haemolymph sample was estimated using an improved Neubauer haemocytometer, and total DNA was extracted by the previously described methods. The amplification reaction mixtures contained 0.1 to $100 \mathrm{ng}$ genomic DNA, $10 \mathrm{mM}$ Tris-HCl, $\mathrm{pH}$ 9.0, $50 \mathrm{mM} \mathrm{KCl}, 0.1 \%$ Triton X-100 (v/v), $1.5 \mathrm{mM} \mathrm{MgCl}_{2}, 100 \mu \mathrm{M}$ dNTPs, 10 pmol each primer, 1 unit of Taq polymerase (Promega), and sterile deionised water to a final volume of $20 \mu \mathrm{l}$. Reactions were overlaid with $10 \mu \mathrm{l}$ of mineral oil. Thermal cycling conditions were as follows: denaturation at $94^{\circ} \mathrm{C}$ for $30 \mathrm{~s}$; primer annealing at $57^{\circ} \mathrm{C}$ for $1 \mathrm{~min}$; chain extension at $72^{\circ} \mathrm{C}$ for $1 \mathrm{~min}$; repeated for 35 cycles, with a final cycle incorporating a 7 min extension step at $72^{\circ} \mathrm{C}$. A $5 \mu \mathrm{l}$ aliquot of each PCR reaction was checked for amplification products by $1.5 \%(\mathrm{w} / \mathrm{v})$ agarose gel electrophoresis and ethidium bromide staining. Images were captured using a gel documentation system (Appligene).

The PCR primers were tested for specificity against genomic DNA samples (100 ng) isolated from Hematodinium-infected and uninfected Nephrops norvegicus, H. perezi, Cancer pagurus, Callinectes sapidus, several other crustacean species common to the UK (detailed in Table 1), a Mesanophrys-like ciliate found infecting $N$. norvegicus, and the free-living dinoflagellates Gymnodinium catenatum and Alexandrium tamarense. Reaction conditions were as described above.

As part of ongoing studies, samples of Hematodinium-infected haemolymph were obtained from Nephrops norvegicus collected from the Clyde Sea Area, the Fladen and North Minch fishing grounds in Scotland, the Irish Sea and the Swedish Skagerrak fishing grounds. Total genomic DNA from $100 \mu \mathrm{l}$ haemolymph samples was extracted and the PCR assay performed as described above. Total genomic DNA was also extracted from individual amphipods (Orchomene nanus) and the PCR assay was carried out as described above. 
DNA probe synthesis and in situ hybridisation. DNA probes were synthesised by incorporation of digoxygenin-11-dUTP (DIG, Roche) during PCR using primer sets 18S F2/ITS R1 and 18S F1/18S R1. PCR was carried out using $100 \mathrm{ng}$ of genomic DNA extracted from parasite cells from an in vitro culture of Hematodinium sp. Locations and sequences of the primers used to synthesise the probes are given in Table 2 . Reaction conditions were followed as suggested by the manufacturer, with annealing temperatures of 52 and $56^{\circ} \mathrm{C}$ for primers $18 \mathrm{~S}$ F2/ITS R1 and 18S F1/18S R1, respectively. Incorporation of DIG was indicated by an increase in molecular mass when amplification products were visualised on ethidium bromide-stained agarose gels. The labelled PCR product was gelextracted and purified using a QIAquick gel-extraction kit (Qiagen). Probe concentration was estimated by side-by-side comparison of a diluted series of the probes and a DIG-labelled control of known concentration in a spot test on nylon membrane following the manufacturer's protocols.

Paraffin-embedded tissue sections from Hematodinium sp.-infected Nephrops norvegicus and Carcinus maenas were cut at $6 \mu \mathrm{m}$ thickness, placed on salinised slides, and baked for $45 \mathrm{~min}$ at $60^{\circ} \mathrm{C}$. Sections were de-paraffinised (xylene, $2 \mathrm{~min}$ ), rehydrated in an ethanol series (1 min each ethanol grade, 100, 90 and $70 \% \mathrm{v} / \mathrm{v})$, washed in distilled water, and permeabilised with 10 to $50 \mu \mathrm{g} \mathrm{ml}^{-1}$ Proteinase $\mathrm{K}$ in TNE buffer (50 mM Tris- $\mathrm{HCl}, 10 \mathrm{mM} \mathrm{NaCl}, 1$ mM EDTA, pH 7.4) for $30 \mathrm{~min}$ at $37^{\circ} \mathrm{C}$ in a humid chamber. Proteolysis was inactivated by two 1 min washes in $20 \mathrm{ml}$ PBS (phosphate-buffered saline) followed by equilibration in $20 \mathrm{ml} 2 \times$ SSC (saline sodium citrate). Samples were prehybridised in $500 \mu \mathrm{l}$ prehybridisation buffer $(2 \times$ $\mathrm{SSC}[20 \times \mathrm{SSC}=3 \mathrm{M} \mathrm{NaCl}, 0.3 \mathrm{M} \mathrm{Na}$-citrate, $\mathrm{pH}$ 7.0], $50 \%[\mathrm{v} / \mathrm{v}]$ formamide, $5 \times$ Denhardt's solution and $100 \mu \mathrm{g} \mathrm{ml}^{-1}$ herring sperm DNA) in a humid chamber for $60 \mathrm{~min}$ at $37^{\circ} \mathrm{C}$. The prehybridisation buffer was replaced with 50 to $100 \mu \mathrm{l}$ hybridisation buffer $(2 \times \mathrm{SSC}$, $50 \%$ [v/v] formamide, $5 \times$ Denhardt's solution, $100 \mu \mathrm{g}$ $\mathrm{ml}^{-1}$ herring sperm DNA and $1 \%$ [v/v] dextran sulphate) containing $0.1 \mathrm{ng} \mathrm{\mu l}^{-1}$ heat-denatured DIGlabelled probe. After applying glass coverslips, sections were placed on a heating block at $95^{\circ} \mathrm{C}$ for $5 \mathrm{~min}$ to denature the target DNA, then immediately put on ice for $5 \mathrm{~min}$ and allowed to hybridise overnight in a humid chamber at $42{ }^{\circ} \mathrm{C}$. Post-hybridisation washes included $2 \times \mathrm{SSC}$ at room temperature, twice for $5 \mathrm{~min}$, and $0.1 \times \mathrm{SSC}$ at $42^{\circ} \mathrm{C}$, once for $10 \mathrm{~min}$, followed by equilibration in $20 \mathrm{ml}$ maleic acid buffer (100 mM maleic acid, $150 \mathrm{mM} \mathrm{NaCl}, \mathrm{pH}$ 7.5). Sections were blocked with $500 \mu$ l blocking buffer (maleic acid buffer plus $1 \%$ [w/v] blocking reagent: Roche) at $37^{\circ} \mathrm{C}$ for $15 \mathrm{~min}$ followed by incubation for $1 \mathrm{~h}$ at $37^{\circ} \mathrm{C}$ with $500 \mu \mathrm{l}$ of
Table 1. Use of Hematodinium-specific PCR primer set 18S F2 and ITS1 R1 against other dinoflagellate, ciliate and decapod crustacean DNA samples. +: single amplification product of $380 \mathrm{bp}_{i}-$ : no amplification product or amplification product of incorrect size

\begin{tabular}{|lc|}
\hline Genomic DNA template & $\begin{array}{c}\text { PCR } \\
\text { diagnosis }\end{array}$ \\
\hline Alexandrium tamarense CCAP 1119/5 & - \\
Gymnodinium catenatum CCAP 1117/6 & - \\
Mesanophrys-like ciliate & - \\
Carcinus maenas & - \\
Necora puber & - \\
Cancer pagurus & - \\
Maja squinado & - \\
Liocarcinus depurator & - \\
Pagurus bernhardus & - \\
Callinectes sapidus & - \\
Hematodinium-infected Nephrops norvegicus & + \\
Hematodinium-infected Cancer pagurus & + \\
Hematodinium-infected Callinectes sapidus & - \\
\hline
\end{tabular}

dilute anti-DIG-alkaline phosphatase antibody (Roche) diluted 1:1000 in blocking buffer. Unbound antibody was removed by two 5 min washes in $20 \mathrm{ml}$ washing buffer (maleic acid buffer plus $0.3 \%$ [v/v] Tween 20) followed by one 5 min wash in $20 \mathrm{ml}$ detection buffer (100 mM Tris- $\mathrm{HCl}, 100 \mathrm{mM} \mathrm{NaCl}, 50 \mathrm{mM} \mathrm{MgCl}$, $\mathrm{pH}$ 9.5); 5-bromo-4-chloro-3-indolyl phosphate/nitro blue tetrazolium (NBT/BCIP) was diluted (1/50 dilution of stock solution) in detection buffer and $200 \mu$ l was added to sections and incubated at room temperature $\left(22^{\circ} \mathrm{C}\right)$ in the dark for 2 to $6 \mathrm{~h}$. The reaction was stopped with a $20 \mathrm{ml}$ TE buffer wash $\left(10 \mathrm{mM}\right.$ Tris- $\mathrm{HCl}_{\text {, }}$ 1 mM EDTA, pH 8.0). Slides were washed in doubledistilled $\mathrm{H}_{2} \mathrm{O}$ and counterstained with $1 \%$ (w/v) eosin for $1 \mathrm{~min}$, followed by ethanol dehydration (1 min each ethanol grade, 100, 90 and $70 \% \mathrm{v} / \mathrm{v})$, and mounted in aqueous mounting medium (histomount). Hybridisation conditions were optimised by varying the concentration of Proteinase K (10 to $50 \mathrm{\mu g} \mathrm{ml}^{-1}$ ) and length of incubation (15 to $60 \mathrm{~min}$ ), and the concentration of DIG-labelled DNA probes ( 0.1 to $1 \mathrm{ng}^{-1} \mathrm{l}^{-1}$ heat-denatured DIG-labelled probe). Negative controls included samples treated without the addition of DIG-labelled probe as well as the use of uninfected tissue sections.

\section{RESULTS}

\section{Hematodinium rDNA sequences}

A single $680 \mathrm{bp}$ amplification fragment was produced when template DNA samples from the in vitro culture were used in conjunction with the nucleotide primers previously described by Hudson \& Adlard 


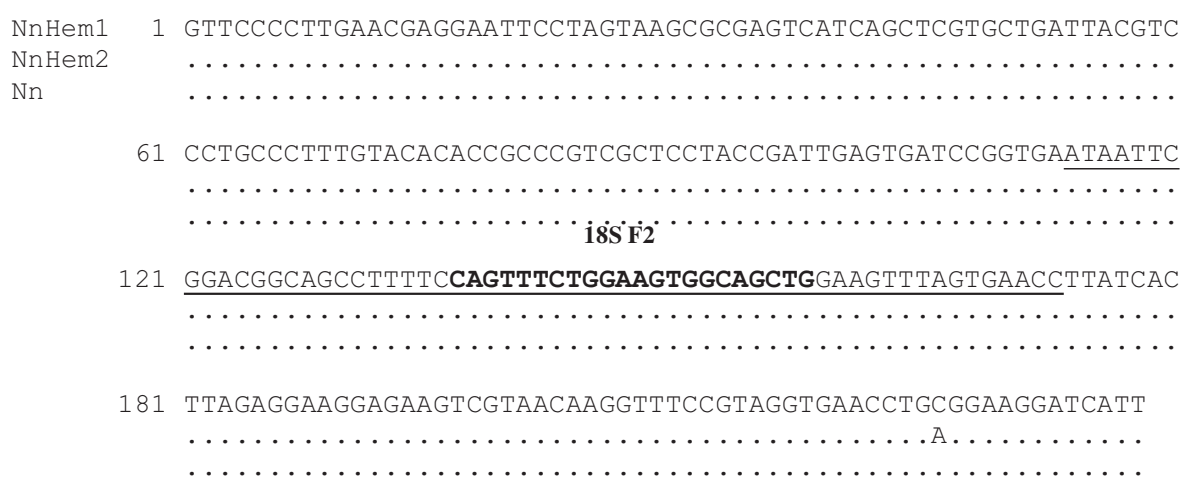

NnHem1 $\quad 1 \quad$ CGCACGAATAATCAATAAAAAACACCGTGAACCTTGGCCATTAGC-ACGAGCAAAAAAGC
NnHem2
Nn

60 GCATGCGCATGCTGCATGCCCCCGCCGCCGCCGCCGCCTCCGCTGTGTGTGTGTGTGTGT

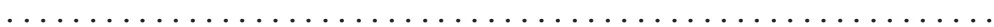
$\ldots \ldots$.... . . . ... .....А..............

120 G--GGGGTGTTTGTGTGTGCGCGTTCGTGCTACTAAGGGCTGTGAGAGATGGGGAAC-CA

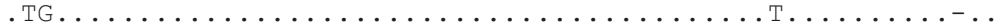

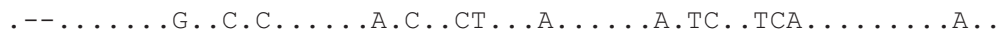

177 CCTCTC-CAАATATTTCTCCAGGCCCACGTTTGTTTTCCTTAT--AАTAАСTCTCTAАTT

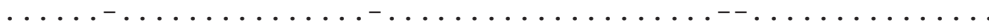

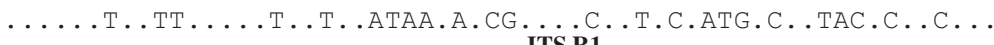
ITS R1

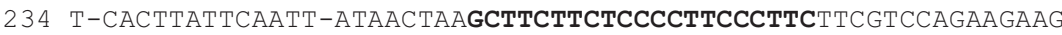

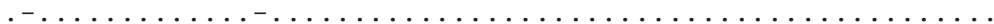
AA...A......T.....GT..C.TC.TC.... .A------------------

292 AAGAAGGAGGAGGAGGAGGAGGA

...................

Fig. 1. Hematodinium spp. Alignments of nucleotide sequences consisting of the $3^{\prime}$ end of the $18 \mathrm{~S}$ (upper alignment) and $5^{\prime}$ end of the first internal transcribed spacer (ITS1) region (lower alignment) of the ribosomal DNA gene complex from 2 isolates sequenced as part of this study and the Nephrops norvegicus Hematodinium sp. sequence from Hudson \& Adlard (1996) (Nn). Isolate NnHem1: Hematodinium sp. from a continuous in vitro culture first isolated in 1992 (GenBank Accession No. DQ084245); NnHem2: Hematodinium sp.-infected N. norvegicus haemolymph sample from 2000 (GenBank Accession No. DQ084246). Nucleotide region underlined in 18S sequence indicates V9 domain; boldface print indicates PCR primers 18S F2 and ITS R1; dots: conserved nucleotides; dashes: missing nucleotides

(1994). However, multiple-reaction products were produced using template DNA from infected lobster haemolymph, reiterating the need for the development of molecular diagnostics with increased specificity. The $680 \mathrm{bp}$ products from both PCR amplifications were successfully cloned into the plasmid vector, sequenced and aligned with the Nephrops norvegicus Hematodinium sp. sequence from Hudson \& Adlard (1996) (Fig. 1). The 3' end of the $18 \mathrm{~S}$ gene was almost totally conserved between all isolates, the only variation being 1 nucleotide at Position 236 bp. Comparison of these sequences with sequences held at GenBank using BLAST confirmed that the 3 ' end of the 18 S gene has a high level of identity (95\%) with other dino- flagellate 18S rDNA gene sequences. Both sequences were deposited in GenBank (Accession Nos. DQ084245 and DQ084246)

The 5' region of ITS1 showed only a small number of nucleotide variations between the isolates sequenced in this study (98\% identical); however, conserved regions were identified where primers could be designed to anneal (Fig.1). Sequence similarity of the published ITS1 region of the Hematodinium species from Nephrops norvegicus (Hudson \& Adlard 1996) to the isolates used in this study and another (H. J. Small unpubl. data) was much lower $(77 \%)$, justifying the present efforts to obtain sequence information for $N$. norvegicus Hematodinium sp. isolates. 
Table 2. Oligonucleotide primer sequences and annealing positions, designed to bind to Hematodinium 18S and ITS1 regions of the rDNA gene complex for use in PCR assays and construction of DNA probes

\begin{tabular}{|c|c|c|c|}
\hline Primer & Sequence $5^{\prime}-3^{\prime}$ & Position & Purpose \\
\hline 18S F1 & GTTCCCCTTGAAGGAGGAATTC & $\begin{array}{l}216-238 \text { bp upstream } \\
\text { 18S/ITS1 boundary }\end{array}$ & Probe 2 \\
\hline 18S F2 & CAGTTTCTGGAAGTGGCAGCTG & $\begin{array}{l}80-102 \text { bp upstream } \\
\text { 18S/ITS1 boundary }\end{array}$ & PCR and Probe 1 \\
\hline 18S R1 & AGCTGCCACTTCCAGAAACT & $\begin{array}{l}81-101 \text { bp upstream } \\
\text { 18S/ITS1 boundary }\end{array}$ & Probe 2 \\
\hline ITS R1 & GAAGGGAAGGGGAGAAGAAGC & $\begin{array}{l}256-277 \text { bp downstream } \\
\text { 18S/ITS1 boundary }\end{array}$ & PCR and Probe 1 \\
\hline
\end{tabular}

\section{PCR primer design, sensitivity and specificity}

A new forward primer was synthesised (18S F2) which was specific to an area within the variable V9 domain of the $3^{\prime}$ end of the $18 \mathrm{~S}$ gene (80 to $102 \mathrm{bp}$ upstream of the 18S/ITS1 boundary). The V9 domain has previously been shown to be highly conserved between Hematodinium species compared with other dinoflagellates (Hudson \& Adlard 1996). A new reverse primer was also synthesised (ITS R1), specific to an area within the ITS1 sequence 256 to $277 \mathrm{bp}$ downstream of the 18S/ITS1 boundary. The positions and sequences of primer sets are shown in Table $2 \&$ Fig. 1. Amplification of DNA from Hematodiniuminfected Nephrops norvegicus haemolymph using the primer pair 18S F2 and ITS R1 led to the production of a diagnostic band of $380 \mathrm{bp}$ from $1 \mathrm{ng}$ or more DNA (Fig. 2). This band was not produced using a sample of 100 ng DNA from uninfected haemolymph. Based on initial cell counts of the parasite numbers in the haemolymph, $1 \mathrm{ng}$ genomic DNA is equivalent to 0.6 parasite cells. The Hematodinium-specific PCR primer pair did not generate a PCR product of appropriate size when using genomic DNA preparations

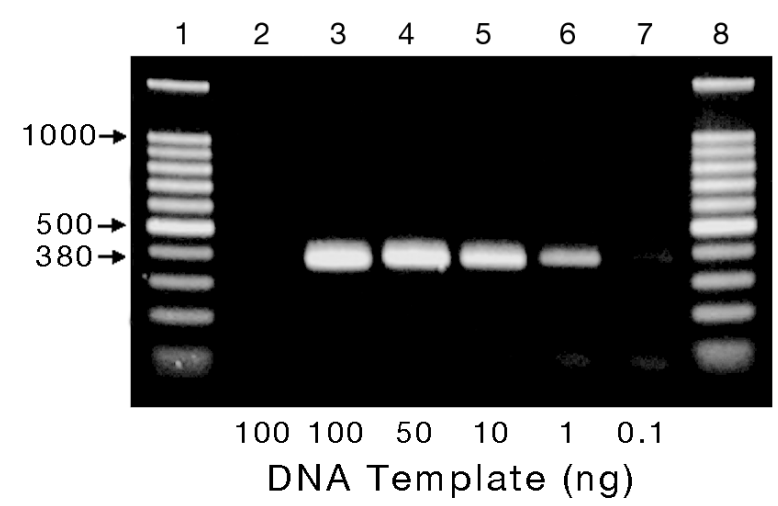

Fig. 2. Sensitivity of PCR assay for detection of Hematodinium

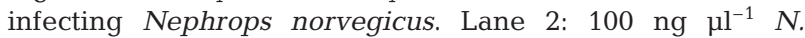
norvegicus host DNA control; Lanes 3 to 7 : infected haemolymph DNA template concentrations, 100, 50, 10, 1, $0.1 \mathrm{ng}$ $\mu^{-1}$; Lanes 1 and 8: $100 \mathrm{bp}$ molecular weight marker from $H$. perezi, a Mesanophrys-like ciliate found infecting $N$. norvegicus, 2 toxin-producing dinoflagellate species, and a number of other crustacean species (Table 1). However, the primer pair did generate an appropriate reaction product when the PCR assay was performed with genomic DNA templates prepared from Hematodinium-infected N. norvegicus haemolymph and Hematodinium-infected Cancer pagurus hepatopancreas tissue.

\section{Detection of Hematodinium in Nephrops norvegicus and Orchomene nanus}

Hematodinium infections in haemolymph samples of Nephrops norvegicus from the Clyde Sea Area, North Minch and Fladen were detectable by PCR (Fig. 3). Hematodinium infections were also detected in $N$. norvegicus haemolymph samples from the Irish Sea and the Swedish Skagerrak (data not shown). Sequencing of reaction products confirmed that only Hematodinium DNA was amplified. Variation in PCR product intensity was observed between haemolymph samples from the different locations, presumably re-

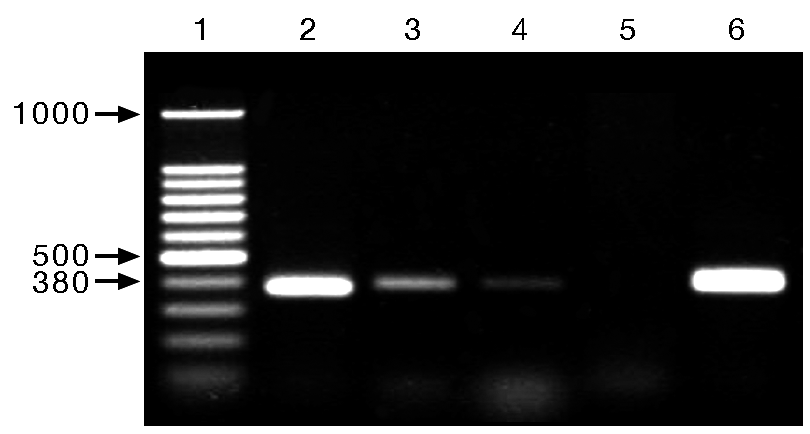

Fig. 3. Verification of PCR assay on Hematodinium-infected Nephrops norvegicus haemolymph samples from different geographical locations. Lane 1: $100 \mathrm{bp}$ molecular weight marker; Lanes 2 to $4: 100 \mathrm{ng}^{-1}$ total genomic DNA from haemolymph of infected $N$. norvegicus collected from Clyde Sea, Fladen and North Minch, respectively; Lane 5: N. norve-

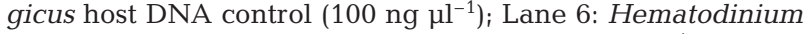
DNA control from in vitro culture $\left(50 \mathrm{ng} \mathrm{Hl}^{-1}\right)$ 

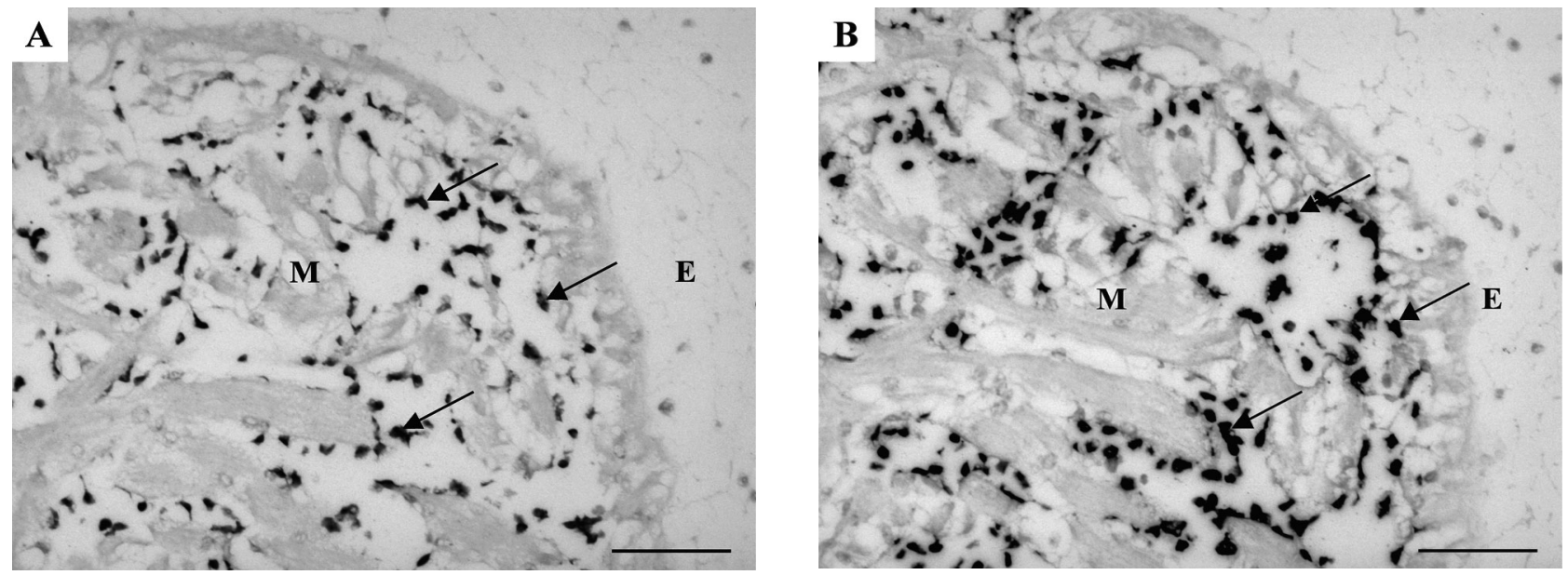

Fig. 4. Nephrops norvegicus. Hybridisation of (A) Probe 1 and (B) Probe 2 with Hematodinium parasites (arrows) in myocardial heart-tissue sections of the lobster. M: myocardium; E: epicardium. Scale bars $=100 \mu \mathrm{m}$

flecting differences in parasite loading of the samples (as rDNA sequences were identical over the oligonucleotide primer regions used: H. J. Small unpubl. data).

PCR screening of Orchomene nanus DNA samples from August 2000 indicated that 5 of 13 amphipods were potentially infected with Hematodinium sp. However, when screening was repeated with larger samples $(\mathrm{n}=40)$ obtained in March 2003 and August 2003, no indication of infection was observed.

\section{In situ hybridisation}

DNA Probes 1 and 2 hybridised to parasite cells present in paraffin-embedded myocardial heart tissue sections, prepared from Hematodinium sp.-infected Nephrops norvegicus (Fig. 4). There was negligible background hybridisation observed for both DNA probes used. A marked increase in signal intensity was observed when using Probe 2 compared to Probe 1 against parasites in heart tissues. Alteration of DIGlabelled Probe 1 concentration and incubation time did not enhance hybridisation and, as a result, signal intensity. Because of this, only Probe 2 was used in further hybridisation studies. No signal was observed for negative-control uninfected samples or preparations where DNA Probe 2 was absent from hybridisation reactions (Fig. 5). Probe 2 hybridised clearly with parasite cells in the haemal space of the hepatopancreas and gill filaments from infected $N$. norvegicus (Fig. 6). Probe 2 also hybridised well with presumptive Hematodinium cells present in haemal spaces of the hepatopancreas and gill filament tissue sections from Carcinus maenas (Fig. 7).
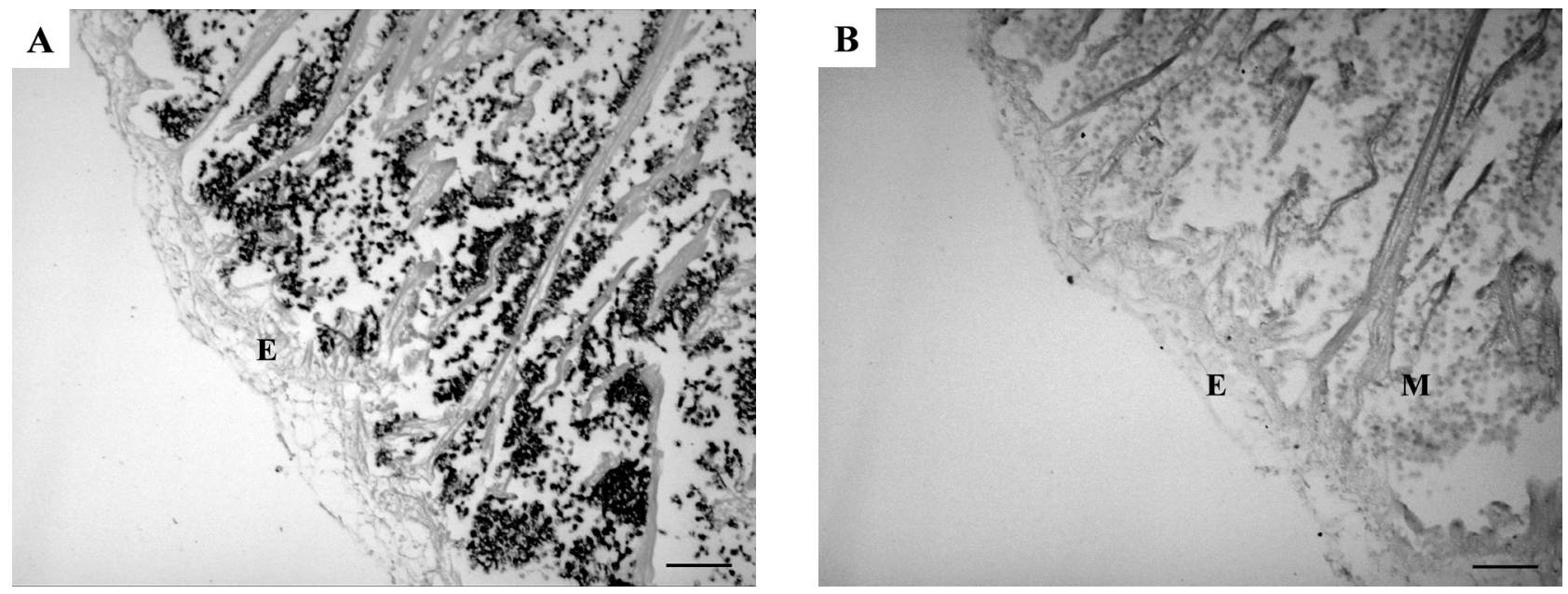

Fig. 5. Nephrops norvegicus. In situ hybridisation control reactions on Hematodinium-infected N. norvegicus heart-tissue sections when Probe 2 is (A) present and (B) absent from hybridisation buffer. M: myocardium; E: epicardium. Scale bars = $100 \mu \mathrm{m}$ 

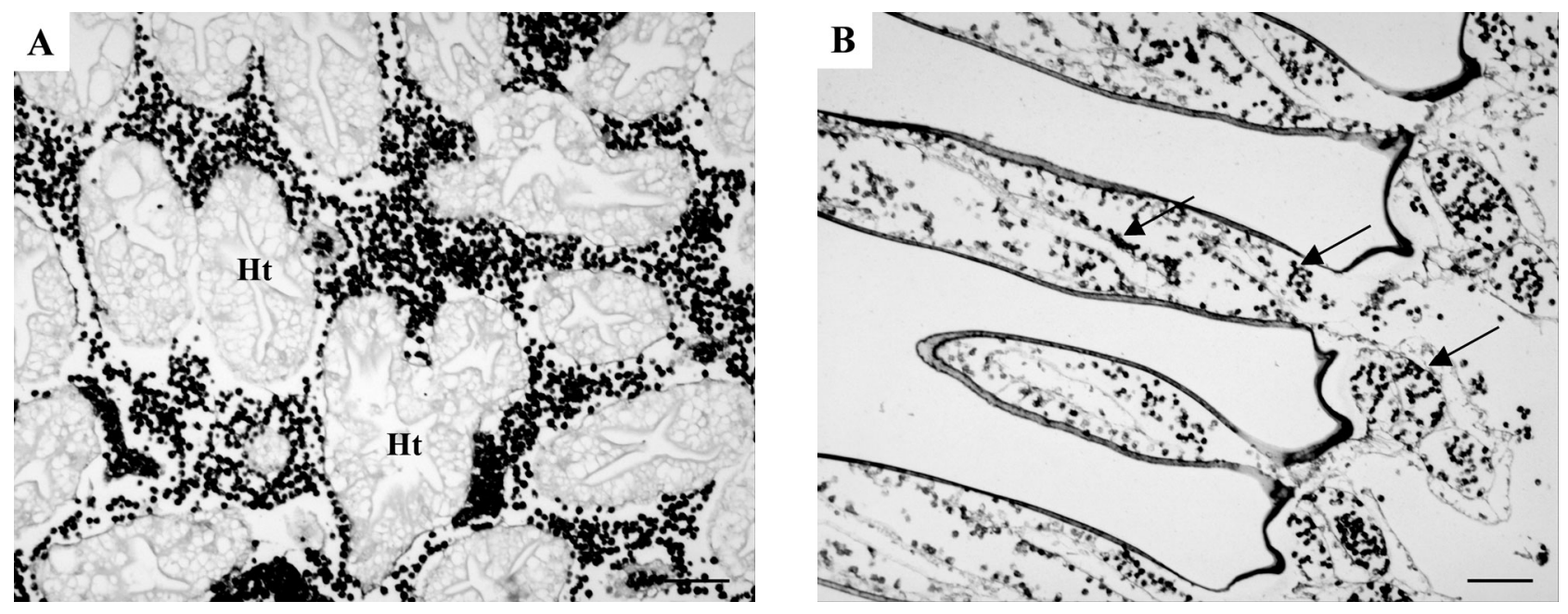

Fig. 6. Nephrops norvegicus. Hybridisation of Probe 2 with Hematodinium cells in (A) haemal space of hepatopancreas and (B) gills of $N$. norvegicus tissue sections. Ht: hepatopancreatic tubule; arrows indicate parasites. Scale bars $=100 \mu \mathrm{m}$

\section{DISCUSSION}

Methods developed for the diagnosis of Hematodinium spp. infection in the Norway lobster include the examination of lobsters for signs of gross infection by carapace discolouration, monitoring aggregation of parasites in the pleopods, and several immunoassays. In this study, molecular probes were developed and applied for the diagnosis of Hematodinium infection in Nephrops norvegicus and other crustaceans. The rDNA gene locus was chosen as a target region for the design of molecular probes based on Hudson \& Adlard's (1996) finding that there was a significant degree of sequence variation in this gene locus between Hematodinium species. However, the rDNA sequences obtained were never deposited in GenBank or any other database; hence, amplification and sequencing of Hematodinium sp. isolates from $N$. norvegicus were carried out as part of this study. Cloning of the $3^{\prime}$ end of the $18 \mathrm{~S}$ and $5^{\prime}$ end of the ITS1 rDNA genes from Hematodinium species infecting $N$. norvegicus revealed that the $3^{\prime}$ end of the $18 \mathrm{~S}$ gene was conserved (apart from 1 polymorphic nucleotide site) between the 2 isolates used in the study, but the ITS1 sequences showed a number of nucleotide variations (5 over $315 \mathrm{bp}$ ). Of considerable importance is the finding that Hudson \& Adlard's (1996) sequence of the ITS1 rDNA region was only $77 \%$ identical to the sequences obtained as part of this study and another (H. J. Small unpubl. data), and cautions against interpretation and use of any Hematodinium sp. sequences published as part of that study. Sequencing of other rDNA genes (and others such as actin) from Hematodinium isolates from their various hosts is essential for the design of molecular diagnostics, and required to accurately delineate between species and strains of this economically important parasite.

The primer set 18S F2 and ITS R1 efficiently amplified parasite DNA in the presence of host DNA, resulting in the production of a diagnostic band of $380 \mathrm{bp}$ from genomic DNA samples of at least $1 \mathrm{ng}$, equivalent to 0.6 parasite cells per sample. This is a considerable improvement in sensitivity compared to the ELISA (which requires about $5 \times 10^{4}$ parasites $\mathrm{ml}^{-1}$ : Small et al. 2002) The inhibitory effect of host DNA/PCR inhibitors or method of DNA extraction from samples has not been investigated, but warrants further consideration as several diagnostic assays for other shellfish pathogens have shown that these factors can effect the sensitivity of PCR assays (Kleeman \& Adlard 2000, Audemard et al. 2004).

The PCR assay was further validated by amplification of parasite DNA from samples of Hematodinium sp.-infected Nephrops norvegicus haemolymph from geographically separate waters. The differences in PCR product intensity (Fig. 3) probably represent different levels of infection. This may also correlate with a different seasonal pattern of infection from the Clyde Sea Area, as the host moult period has been implicated in Hematodinium infection seasonality (Field et al. 1992) and $N$. norvegicus moulting is thought to vary between geographical location in UK waters (J. Atkinson pers. comm.). The primers used did not produce any amplification signal when DNA templates prepared from several other crustacean species were used, indicating that these primers can be used to investigate whether the Hematodinium species infecting $N$. norvegicus also occurs in these crustaceans.

In situ hybridisation studies using the DIG-labelled DNA Probe 1, constructed using the same primers 

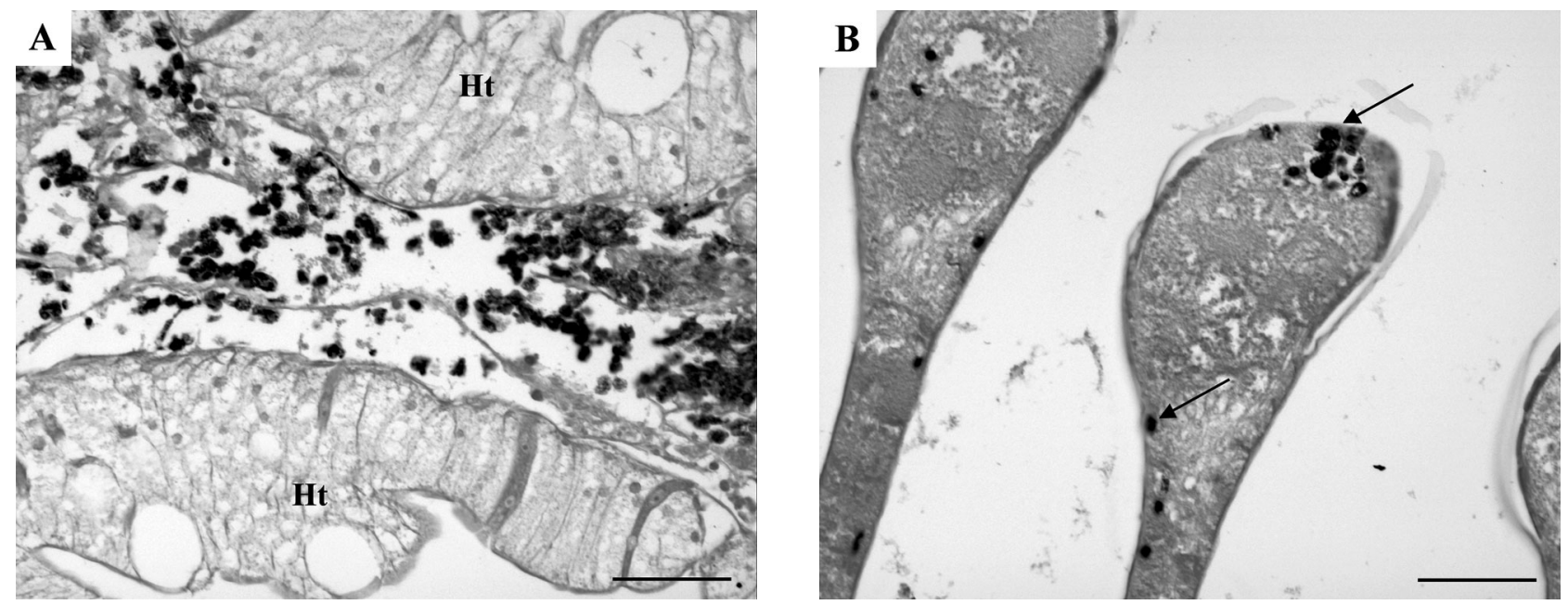

Fig. 7. Carcinus maenas. Hybridisation of Probe 2 with Hematodinium cells in (A) haemal space of hepatopancreas and (B) gill tips of $C$. maenas tissue sections. Ht: hepatopancreatic tubule; arrows indicate parasites. Scale bars $=10 \mu \mathrm{m}$. (Material supplied by Dr. G. Stentiford, CEFAS Weymouth Laboratory)

used for the PCR assay which span the 18S and ITS1 rDNA regions, localised individual parasites in lobster tissues. However, the signal from the probe was weak and could not be improved by either incubating the section with a higher concentration of probe or by increasing the incubation time. In contrast, Probe 2 constructed using Primers 18S F1 and 18S R1, which amplify conserved 18S rDNA only, gave a very intense signal when hybridising to parasite cells within paraffin-embedded sections using the same reaction conditions as Probe 1. Kleeman et al. (2002b) reported variations in sensitivity and signal intensity between different 18S/ITS1-based DIG-labelled probes for Marteilia sydneyi and $M$. refringens. This suggests that the observed difference in signal intensity between Hematodinium Probes 1 and 2 may reflect the availability of target sequence; ITS regions are excised from the mRNA in the cell cytoplasm prior to ribosomal construction and so are not available for probe hybridisation. Alternatively, the shorter length of Probe 2 may assist in increased binding to target sequences and result in an increased signal. Probe 2, based on $18 \mathrm{~S}$ rDNA, efficiently hybridised to parasites in the hepatopancreas and gill tissues of Nephrops norvegicus and Carcinus maenas. The results presented suggest that Probe 2 is able to detect Hematodinium species in at least 2 different hosts and is likely to be genus-specific owing to the conserved nature of the $18 \mathrm{~S}$ rDNA. Consequently, it could be used to confirm and investigate latent Hematodinium infection in a wide range of crustacean hosts.

Several life history stages of Hematodinium sp. from Nephrops norvegicus have been described from in vitro cultures (Appleton \& Vickerman 1998), but of these only a few forms have been observed during natural infection in the lobster. It was suggested by Appleton \& Vickerman (1998) that ingestion of Hematodinium dinospores takes place during suspensionfeeding by the lobster, and that initiation of infection takes place after penetration of the gut wall by the dinospores. Others have suggested that cuticle tissues of crustaceans damaged during moulting may be the sites of parasite entry (Eaton et al. 1991). Molecular techniques have been used to identify the portal of entry of PKX (phylum Myxozoa) in salmonids (Morris et al. 2000), and to detect different life cycle stages of Marteilia sydneyi (Kleeman et al. 2002a). The DNA probes developed for Hematodinium will likely be useful for addressing similar issues. They will be valuable in monitoring low-level infections in naturally and experimentally infected lobsters, and also in the identification of life history stages previously unseen.

One issue that we have addressed is the mechanism of transmission of Hematodinium spp. The lack of success in transmission experiments with cultured Hematodinium and infected haemolymph (Vickerman 1994) indicates that an undiscovered intermediate host may be required for completion of the parasite life cycle and its ability to infect Nephrops norvegicus (Appleton \& Vickerman 1998). This hypothesis has also been raised for a number of aquatic pathogens, including Marteilia refringens, which infects copepods and oysters (Audemard et al. 2002) and the myxosporean Ceratomyxa shasta, which infects an annelid worm and salmonids (Bartholomew et al. 1997).

Several amphipods predate or scavenge dead crustaceans (Templeman 1954, Scarratt 1965), and have previously been reported to be infected by dinoflagellates (Johnson 1986). Messick \& Shields (2000) also 
suggested that several amphipods collected during prevalence studies for Hematodinium perezi in Callinectes sapidus were potentially infected with this parasite. Thus, the PCR primers developed in the present study were used to investigate Orchomene nanus as a possible secondary host or transmission vector for Hematodinium spp. This amphipod species is a generalist scavenger, with a preference for crustacean carrion (Moore \& Wong 1995), and as such probably feeds on dead Nephrops norvegicus with large numbers of parasites present. Analysis of samples of $O$. nanus collected from the Clyde Sea Area and assayed by PCR revealed that in August 2001, 5 of 13 amphipods were positive for the presence of Hematodinium spp. Sequencing of a PCR product from the amphipod screen confirmed that it was Hematodinium DNA that was amplified, with $98 \%$ homology in the ITS1 region to other Hematodinium isolates from the Norway lobster (H. J. Small unpubl. data). Considering the size of Hematodinium dinospores (11 to $20 \mu \mathrm{m}$ long, 4.5 to $11.5 \mu \mathrm{m}$ wide), they could be ingested by the amphipod and result in the positive PCR signal from the gut contents, or from infection of different tissues. However, the possibility of parasites adhering to the exterior surface of the amphipod cannot be ruled out. Unfortunately, no individual amphipods were retained for in situ hybridisation studies to localise the parasite in these samples. When amphipod sampling and the PCR assay were repeated in March 2003 and August 2003, no Hematodinium DNA could be detected. Thus, the determination of the prevalence of Hematodinium in $O$. nanus, its location, and the importance, or not, of $O$. nanus in the life cycle of Hematodinium spp. requires further experimental research.

In conclusion, the combined use of the PCR primers and DNA Probe 2 will prove valuable in confirming Hematodinium species infection in crustaceans and elucidating the life cycle of Hematodinium spp. in Nephrops norvegicus and other hosts.

Acknowledgements. H.J.S. was the recipient of a Natural Environment Research Council Studentship (NER/S/A/2000/ 03368). We thank G. Stentiford, B. Mouat, R. Briggs and K. Frohlund for Hematodinium sp. samples. Thanks go to J. Moss, who critically read the manuscript.

\section{LITERATURE CITED}

Altschul SF, Gish W, Miller W, Myers EW, Lipman DJ (1990) Basic local alignment search tool. J Mol Biol 215: 403-410

Appleton PL, Vickerman KV (1998) In vitro cultivation and development cycle in culture of a parasitic dinoflagellate (Hematodinium sp.) associated with mortality of the Norway lobster (Nephrops norvegicus) in British waters. Parasitology 116:115-130
Appleton PL, Field RH, Vickerman KV, Atkinson RJA, Taylor AC, Rogerson A, Neil DM (1997) Mortality of Nephrops norvegicus on the west coast of Scotland. Report to MAFF CSG, March 1997. Ministry of Agriculture, Fisheries and Food, Lowestoft

Audemard C, Le Roux F, Barnaud A, Collins C and 6 others (2002) Needle in a haystack: involvement of the copepod Paracartia grani in the life-cycle of the oyster pathogen Marteilia refringens. Parasitology 124:315-323

Audemard C, Reece KS, Burreson EM (2004) Real-time PCR and quantification of the protistan parasite Perkinsus marinus in environmental waters. Appl Environ Microbiol 70:6611-6618

Bartholomew JL, Whipple MJ, Stevens DG, Fryer JL (1997) The life cycle of Ceratomyxa shasta, a myxosporean parasite of salmonids, requires a freshwater polychaete as an alternative host. J Parasitol 83:859-868

Briggs RP, McAliskey M (1996) The prevalence of Hematodinium in Irish Sea Nephrops. ICES Nephrops SG, Lorient

Briggs RP, McAliskey M (2002) The prevalence of Hematodinium in Nephrops norvegicus from the Western Irish Sea. J Mar Biol Assoc UK 82:427-433

Bushek D, Dungan CF, Lewitus AJ (2002) Serological affinities of the oyster pathogen Perkinsus marinus (Apicomplexa) with some dinoflagellates (Dinophyceae). J Eukaryot Microbiol 49:11-16

Cunningham CO (2002) Molecular diagnosis of fish and shellfish diseases: present status and potential use in disease control. Aquaculture 206:19-55

Eaton WD, Love DC, Botelho C, Meyers TR, Imamura K, Koeneman T (1991) Preliminary results on the seasonality and life cycle of the parasitic dinoflagellate causing bitter crab disease in Alaskan tanner crabs (Chionoecetes bairdi). J Invertebr Pathol 57:426434

Field RH, Appleton PL (1995) A Hematodinium-like dinoflagellate infection of the Norway lobster Nephrops norvegicus: observations on pathology and progression of infection. Dis Aquat Org 22:115-128

Field RH, Appleton PL (1996) An indirect fluorescent antibody technique for the diagnosis of Hematodinium sp. infection of the Norway lobster, Nephrops norvegicus. Dis Aquat Org 24:199-204

Field RH, Chapman CJ, Taylor AC, Neil DM, Vickerman K (1992) Infection of the Norway lobster Nephrops norvegicus by a Hematodinium-like species of dinoflagellate on the west coast of Scotland. Dis Aquat Org 13:1-15

Field RH, Hills JM, Atkinson RJA, Magill S, Shanks AM (1998) Distribution and seasonal prevalence of Hematodinium sp. infection of the Norway lobster (Nephrops norvegicus) around the west coast of Scotland. ICES J Mar Sci 55:846-858

Gasser RB, Zhu XQ (1999) Sequence based analysis of enzymatically amplified DNA fragments by mutation detection techniques. Parasitol Today 15:427-468

Gruebl T, Frischer ME, Sheppard M, Neumann M, Maurer A, Lee RF (2002) Development of an 18S rRNA gene-targeted PCR-based diagnostic for the blue crab parasite Hematodinium sp. Dis Aquat Org 49:61-70

Hillis DM, Dixon MT (1991) Ribosomal DNA: molecular evolution and phylogenetic inference. Q Rev Biol 66:411453.

Hudson DA, Adlard RD (1994) PCR-techniques applied to Hematodinium spp. and Hematodinium-like dinoflagellates in decapod crustaceans. Dis Aquat Org 20: 203-206

Hudson DA, Adlard RD (1996) Nucleotide sequence determination of the partial SSU rDNA gene and ITS1 region of Hematodinium cf. perezi and Hematodinium-like dino- 
flagellates. Dis Aquat Org 24:55-60

Hudson DA, Shields JD (1994) Hematodinium australis n.sp., a parasitic dinoflagellate of the sand crab Portunus pelagicus from Moreton bay, Australia. Dis Aquat Org 19: 109-119

Johnson PT (1986) Parasites of benthic amphipods: dinoflagellates (Duboscquodinida: Syndinidae). Fish Bull 84: 605-614

Kleeman SN, Adlard RD (2000) Molecular detection of Marteilia sydneyi, pathogen of Sydney rock oysters. Dis Aquat Org 40:137-146

Kleeman SN, Adlard RD, Lester RJG (2002a) Detection of the infective stages of the protozoan parasite Marteilia sydneyi in Saccostrea glomerata and their development through to sporogenesis. Int J Parasitol 32:767-784

Kleeman SN, Le Roux F, Berthe F, Adlard RD (2002b) Specificity of PCR and in situ hybridization assays designed for detection of Marteilia sydneyi and M. refringens. Parasitology 125:131-141

Latrouite D, Morizur T, Noel P, Chagot D, Wilhelm G (1988) Mortalite du tourteau Cancer pagurus provoquee par le dinoflagellate parasite: Hematodinium sp. Int Counc Explor Sea Comm Meet K:32

Litaker RW, Vandersea MW, Kibler SR, Reece KS and 6 others (2003) Identification of Pfiesteria piscicida (Dinophyceae) and Pfiesteria-like organisms using internal transcribed spacer-specific assays. J Phycol 39:754-761

Love DC, Rice SD, Moles DA, Eaton WD (1993) Seasonal prevalence and intensity of bitter crab dinoflagellate infection and host mortality in Alaskan tanner crabs Chionoecetes bairdi from Auke Bay, Alaska, USA. Dis Aquat Org 15:1-7

MacLean SA, Ruddell MC (1978) Three new crustacean hosts for the parasitic dinoflagellate Hematodinium perezi (Dinoflagellata: Syndinidae). J Parasitol 64:158-160

Messick GA (1994) Hematodinium perezi infections in adult and juvenile blue crabs Callinectes sapidus from coastal bays of Maryland and Virginia, USA. Dis Aquat Org 19: $77-82$

Messick GA, Shields JD (2000) Epizootiology of the parasitic dinoflagellate Hematodinium sp. in the American blue crab Callinectes sapidus. Dis Aquat Org 43:139-152

Meyers TR, Koeneman TM, Botelho C, Short S (1987) Bitter crab disease: a fatal dinoflagellate infection and marketing problem for Alaskan tanner crabs Chionoecetes bairdi. Dis Aquat Org 3:195-216

Moore PG, Wong YM (1995) Orchomene nanus (Krøyer) (Amphipoda: Lysianassoidea), a selective scavenger of dead crabs: feeding preferences in the wild. J Exp Mar Biol Ecol 192:35-45

Morris DJ, Adams A, Richards RH (2000) In situ hybridisation

Editorial responsibility: Timothy Flegel,

Bangkok, Thailand identifies the gill as a portal of entry for PKX (phylum Myxozoa), the causative agent of proliferative kidney disease in salmonids. Parasitol Res 86:950-956

Newman MW, Johnson CA (1975) A disease of blue crabs (Callinectes sapidus) caused by a parasitic dinoflagellate, Hematodinium sp. J Parasitol 63:554-557

Sambrook J Fritsch EF Maniatis T (1989) Molecular cloning: a laboratory manual, 2nd edn. Cold Spring Harbour Laboratory Press, Plainview, NY

Scarratt DJ (1965) Predation on lobsters (Homarus americanus) by Anonyx sp. (Crustacea, Amphipoda). J Fish Res Board Can 22:1103-1104

Small HJ (2004) Infections of the Norway lobster, Nephrops norvegicus (L.) by dinoflagellate and ciliate parasites. $\mathrm{PhD}$ thesis, University of Glasgow

Small HJ, Wilson S, Neil DM, Coombs GH (2002) Detection of a Hematodinium-like parasitic dinoflagellate in the Norway lobster (Nephrops norvegicus) by ELISA. Dis Aquat Org 52:175-177

Stentiford GD, Neil DM, Atkinson RJA (2001a) The relationship of Hematodinium infection prevalence in a Scottish Nephrops norvegicus population to season, moulting and sex. ICES J Mar Sci 58:814-823

Stentiford GD, Neil DM, Coombs GH (2001b) Development and application of an immunoassay diagnostic technique for studying Hematodinium infections in Nephrops norvegicus populations. Dis Aquat Org 46:223-229

Stentiford GD, Green M, Bateman K, Small HJ, Neil DM, Feist SW (2002) Infection by a Hematodinium-like parasitic dinoflagellate causes pink crab disease (PCD) in the edible crab Cancer pagurus. J Invertebr Pathol 79: 179-191

Taylor DM, Khan RA (1995) Observations on the occurrence of Hematodinium sp. (Dinoflagellata: Syndinidae), the causative agent of bitter crab disease in Newfoundland snow crab (Chionoecetes opilio). J Invertebr Pathol 65: 283-288

Templeman W (1954) Lobsters eaten by sea-fleas. Progress Report of the Atlantic Coastal Station. Fish Res Board Can 60:14-15

Thompson JD, Higgins DG, Gibson TJ (1994) CLUSTAL W: improving the sensitivity of progressive multiple sequence alignment through sequence weighting, positions-specific gap penalties and weight matrix choice. Nucleic Acids Res 22:4673-4680

Vickerman K (1994) Playing at being Pasteur. Int J Parasitol 24:779-786

Wilhelm G, Mialhe E (1996) Dinoflagellate infection associated with the decline of Necora puber crab populations in France. Dis Aquat Org 26:213-219

Submitted: June 13, 2005; Accepted: October 10, 2005

Proofs received from author(s): March 13, 2006 